This item was submitted to Loughborough's Research Repository by the author.

Items in Figshare are protected by copyright, with all rights reserved, unless otherwise indicated.

\title{
Defining and measuring housing affordability using the Minimum Income Standard
}

PLEASE CITE THE PUBLISHED VERSION

https://doi.org/10.1080/02673037.2018.1538447

\section{PUBLISHER}

(C) Taylor \& Francis (Routledge)

\section{VERSION}

AM (Accepted Manuscript)

\section{PUBLISHER STATEMENT}

This is an Accepted Manuscript of an article published by Taylor \& Francis in Housing Studies on 20 December 2018, available online: http://www.tandfonline.com/10.1080/02673037.2018.1538447.

\section{LICENCE}

CC BY-NC-ND 4.0

\section{REPOSITORY RECORD}

Padley, Matt, and Lydia Marshall. 2019. "Defining and Measuring Housing Affordability Using the Minimum Income Standard”. figshare. https://hdl.handle.net/2134/36522. 
Defining and measuring housing affordability using the Minimum Income Standard

Housing Studies

Corresponding author:

Matt Padley

Centre for Research in Social Policy

Loughborough University

Leicestershire

LE11 3TU

m.j.padley@lboro.ac.uk

Co-authors:

Dr Lydia Marshall

NatCen Social Research

35 Northampton Square

London

EC1V OAX

\section{Acknowledgements}

This analysis arose out of the 'A Minimum Income Standard for London' programme of work, funded by Trust for London. Acknowledgements also go to the Housing Studies Association, for awarding Lydia Marshall a bursary to present an earlier version of this paper at the ENHR 2016 conference. 


\begin{abstract}
There is growing concern about a crisis in housing affordability in the UK, renewing longstanding debates about what constitutes 'affordable' housing. The growing use of the private rented sector by low income households has also led to increased interest in understanding the impact of housing costs on living standards. This paper builds on existing work on 'residual income' measures of housing affordability, accepting that what households can afford to pay for housing is related to their ability to cover other costs, and so not directly proportional to income. It proposes a new approach to defining and measuring housing affordability, based on the Minimum Income Standard (MIS). The paper then uses data from the Family Resources Survey (2008/09 to 2015/16) to examine housing affordability within the rented sector across the UK, exploring the value of this measure both in revealing the scale of the 'problem' and assessing the likely impact of suggested interventions.
\end{abstract}

Keywords: Housing affordability, PRS, Social Housing, living standards, Minimum Income Standards

\title{
Introduction
}

Affordability is central to much current housing debate in the UK and internationally.

Despite disagreements about what affordability means, who is facing an affordability crisis and even whether the term is a useful one, over recent years it has, by varying degrees, influenced government policies internationally (see Hui, 2001; Gurran and Phibbs, 2015). In the UK the policy focus has been principally on home ownership rather than the rental 
markets, reflecting a global privileging of ownership over renting (Gilbert, 2015), manifested in recent schemes such as 'Help to Buy' Individual Savings Accounts and equity loans, seeking to help first-time -buyers. This paper seeks to improve clarity over how affordability can be measured, and therefore to suggest better benchmarks against which the achievements of policy can be measured.

Concerns over affordability are not limited to the UK (Austin et al., 2014; Murphy, 2014). In New Zealand for example, the Housing Affordability inquiry (New Zealand Productivity Commission, 2012) was set up in response to a growing concern that housing had become unaffordable, especially for those on low incomes and first time buyers. While in the 1980s the cost of property was around twice the annual disposable income, by 2007 the average house price was five and a half times household income (ibid: 59). Similarly in Australia, the ratio of house prices to household income has increased from around four to seven between 2001 and 2016 (CoreLogic, 2016) and the question of affordability is one that has become a significant political issue (for example, see Senate Economics References Committee, 2015; Gurran and Phibbs, 2015). In the UK, current data relating to the costs of housing reveal why affordability is such a central issue here. In April 2017 the average price of a property was thirteen times median gross annual earnings for full-time workers in London and seven and a half times outside London (Land Registry, 2017; ONS 2017).

While these high costs mean home ownership is out of reach for many, the problem of affordability is not restricted to those who want to purchase property. In 2015/16, London renters in the private sector (PRS) were spending an average of 54 per cent of household income (excluding housing benefit) on rent, while outside London those in the PRS were spending an average of 38 per cent (DCLG, 2017). Social renters spend 43 per cent of household income (excluding housing benefit) on rent in London and 36 per cent outside 
London. Looking further afield, in the United States, rental affordability is identified as the 'main housing problem confronting low-income households' (Newman and Holupka, 2015, p. 116), with the majority of renters in the bottom income decile spending over 30 per cent of their income on rent.

Aggravating the problem of housing affordability in the UK and beyond, the rising cost of housing over recent years has not been matched by commensurate increases in household incomes, particularly following from the global financial crash in 2008. In the UK real terms, median equivalised household income before housing costs fell in 2010/2011 and 2011/2012, stabilising between $2011 / 12$ and $2013 / 14$, and only beginning to rise again in 2014/15 (DWP, 2017a). After housing costs, median income fell each year between $2009 / 10$ to $2012 / 13$, with a small rise in $2013 / 14$ (ibid). The combination of rising housing costs and falling or stagnant incomes suggests that many households need to spend an increasing proportion of their income in order to be able to afford the same standard of housing (see Joyce et al., 2017). This has led to increased talk of a 'crisis' of housing affordability, particularly in the PRS and particularly - although not solely - in London, where costs are significantly higher than in the rest of the UK (see Klier, 2015; Labour Press, 2015; Mann, 2015; Padley et al., 2017a). There is concern not just about the affordability of housing for families on low incomes, but about the impact of the sharp increases in rents discussed above for households further up the income distribution, in terms of decreasing living standards and the ability to save for home ownership.

Housing affordability within the rented sector might not be considered such a critical issue had there not been such significant changes in the tenure structure of the UK housing market (c.f. Katz et al., 2003), the most striking being the rise of the PRS. Between the 1980s and the early 2000s, the proportion of households in the PRS remained stable at 
around 10 per cent. However, since 2003 the PRS has grown rapidly and this is said to have resulted both from a decline in the affordability of home ownership and in the availability of social housing (Lupton and Collins, 2015; PWC, 2015). In all, the number of households in the PRS more than doubled from 2.3 million in 2001 to 5.4 million in 2014 (PWC, 2015). One in five UK households now lives in the PRS, and this is expected to rise to one in four in the next decade, with around 7.2 million households living in the PRS by 2025. Around half of 20-39 year olds now reside in the PRS, up from one in five at the start of the millennium and almost a quarter of households with dependent children now rent privately (PWC, 2015; Shelter, 2015).

In the face of these shifts in the composition of the UK housing market and despite growing concern about the 'crisis' of affordability in UK housing, there remains little consensus about what is meant by 'affordability', what makes housing 'affordable' and what should or could be done to ameliorate the situation. Against this backdrop, this paper proposes a new way of measuring housing affordability using data from the Minimum Income Standard (MIS) research (see Davis et al., 2016; Davis and Padley, 2017), and building on the work of Stone $(1993,2006 a, 2006 b)$ on residual income measures of housing affordability. The work of Stone draws attention to the relationship between housing and non-housing costs which is at the heart of this paper. The paper begins by assessing some of the ways in which housing affordability has been conceptualised and defined previously, examining the limitations of these approaches. We then detail the proposed new measure of housing affordability, using the MIS budgets to identify those households that can be considered to have inadequate residual incomes - that is, incomes that are too low to meet non-housing needs - as a result of 'high' housing costs. The paper proceeds to show how this new measure of housing affordability could be used to assess the current 'problem' of 
affordability in the UK rental sector. The paper concludes by arguing that adopting such a measure could be of significant value in monitoring the effectiveness of policies to address housing affordability.

\section{Defining housing affordability}

In spite of a significant number of contributions from across academic fields, over a long period, the concept of affordability with regard to housing remains a globally contested one (Gabriel et al., 2005; Gurran and Whitehead, 2011; Hancock, 1993). Nearly 30 years ago, Maclennan and Williams (1990) suggested that either the meaning of the term affordability should be clarified or perhaps policy makers and researchers should cease to use the term. More recently, there have been calls to stop using the term 'affordable' as it has come to be used to refer to housing that is anything but affordable to a large proportion of households (cf. Wiles, 2014). Part of the problem with the term is that it encompasses and often confuses a number of related but different issues, including questions of housing quality, public housing policy, income distribution and 'the choices that people make about how much housing to consume relative to other goods' (Quigley and Raphael, 2004, p. 191-2). Stone (2006b) also makes clear that the meaning of 'affordability' is dependent on the context of its use: measures of affordability used to determine eligibility for assistance with housing costs, for example, rest on a different definition of affordability to indicators intended to reveal the extent of housing need within a given society.

Despite the difficulty in using the term for analytical and policy purposes (Stone, 2006a, p. 153), there have been various attempts to define it. This section sets out two approaches to such a definition, in terms that allow 'objective' measurement of whether a 
household has affordable housing. One looks at how much people spend on their housing as a proportion of their income (the ratio approach); the other at how much they have left to spend on non-housing items (the residual income approach).

Before considering these, it is worth noting that a subjective definition of affordability is also conceivable, although problematic. Asking someone if they can afford the housing that they need makes no sense within neoclassical economics, in which housing consumption is a function of income and preferences. Anyone with a roof over their head is meeting their housing need in the best available way, optimising the deployment of limited resources. An alternative view emphasises the lack of choice many people have over housing costs, which would cause someone to report that housing is unaffordable either because they spend so much on it that other essential expenditures are displaced or because they are unable to pay a rent for a home that they consider to meet their basic housing needs, with results such as overcrowding. However, because different individuals are likely to view their housing and non-housing needs differently, subjective measures would be hard to interpret. Objective outcomes such as overcrowding are more easily measured directly, while the adequacy of income relative to housing and non-housing needs are more suitably assessed through the objective criteria outlined below.

\section{Ratio definitions of housing affordability}

Objective definitions look for evidence that households suffer because unavoidable housing costs cause their finances to be stretched excessively. These households are not making rational choices based on what they are willing and/or able to pay and are more likely adapting the ways in which they cover non-housing needs after meeting their shelter costs. The ratio approach to defining housing affordability has emerged as the most widely used 
indicator globally, with the rent-to-income ratio of 30 per cent used as a 'rule of thumb' (see Chaplin and Freeman, 1999; Feins and Lane, 1981; Karmel, 1998; Pedone, 1988; Yip, 1995). It defines housing as unaffordable if a household needs to spend more than a certain proportion of its income on housing (see Figure 1). While it is recognised that establishing a normative standard ratio of housing costs to income across time and space is not possible (Feins and Lane, 1981), ratio indicators have come to be seen and applied as normative standards (Stone, 2006a). While different ratios have been identified as the threshold for affordability at different times and in different countries, related to prevailing norms, within the UK 35 per cent of disposable income has traditionally been used as the standard for housing affordability (Baxter and Murphy, 2017; Reynolds, 2011). In a context of rising housing costs and shifting norms, this ratio 'standard' in the UK, and particularly in London where the cost of housing is greater, is beginning to rise, with some housing organisations using 40 to 45 per cent of income as a threshold (Alakeson and Cory, 2013, p. 15).

Just as there are problems with subjective definitions of housing affordability, so too there are issues with the ratio approach. First, ratios are more often than not set with reference to expenditure data (e.g. Lupton and Collins, 2015); the 'acceptable' proportion of household income to be spent on housing costs has been defined in relation to the proportion households currently spend on housing. Using expenditure data to set a proportional indicator is problematic because in reality households do not necessarily spend what they need to spend. Compared to food or clothing, for example, housing costs are highly variable and relatively inelastic in relation to income. The wide distribution of rents and house values across the UK and within other countries means that any ratio selected, based either on expenditure data or the 'typical' cost of a certain standard of housing provision, will overprovide for some households and underprovide for others (Stone, 
2006a). Second, the ratio approach does not take into account what households need to be able to afford besides their housing costs. As shown in Figure 1, households on higher incomes may be classified as having housing affordability issues on a ratio measure, even though their post-housing cost income is relatively high.

Figure 1. Households spending relatively high ratios of income on housing may nevertheless have more to spend on other items than those with lower ratios but with lower incomes

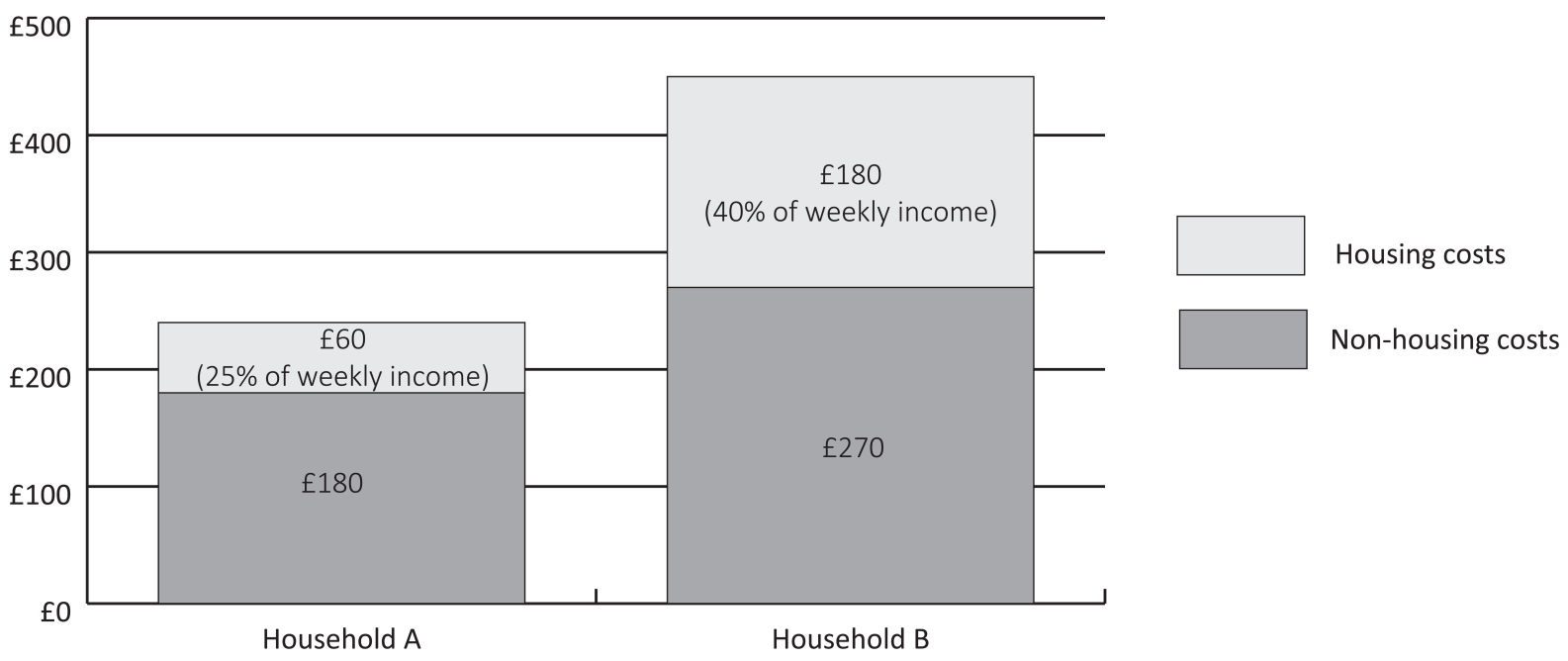

Notes: According to the ratio definition of housing affordability, Household B has an affordability problem (housing costs take up 40 per cent of weekly income), and Household A does not. Household B spend more, and a higher proportion of their income on housing, but have significantly more left to cover their non-housing needs.

As Stone (2006a, p. 163) notes:

'since an affordability standard is intended to measure whether housing costs make an undue claim on household income in relation to other needs, basing such a 
standard on what people actually pay provides no way of assessing whether they are in fact able to achieve some minimum standard for nonshelter necessities'

A household at the upper quartile of the income distribution spending 35 per cent of household income on 'shelter costs' will have more to spend on other essentials, such as food and fuel, than a household at the lowest quartile spending the same proportion of their income on shelter costs (c.f. Karmel, 1998). The 'better-off' household is far more likely to be able to achieve some minimum standard for non-shelter needs after paying for their housing than the latter.

Residual income approaches to defining housing affordability

Since housing costs constitute such a large and generally inflexible claim on household incomes, a growing number of commentators have asserted the need for a 'residual income' concept of housing affordability, capturing what people need to be able to afford after paying for housing (Bramley, 1994; Brownill et al., 1990; Chaplin et al., 1994; London Research Centre, 1996; Stone, 1975, 2006a, 2006b; Whitehead, 1991; Wilcox, 1999; Wilson and Morgan, 1998). Such a definition defines housing as affordable to a given household if they are able to afford to meet their other basic needs - or 'achieve some minimum standard of nonshelter necessities' (Stone, 2006a: 163) - as well as paying for their shelter costs (see Figure 2).

As detailed by Stone (2006b), this approach came to prominence relatively recently in the UK. The issue of 'housing affordability' emerged on the agenda in the UK in the late 1980s/early 1990s, following concern about a perceived 'crisis' in the ability of households to afford rising costs in the owner occupied and social rented sectors (Bramley 1994; 
Hancock, 1993; Kearns, 1992). The 1988 UK Housing Act led to debate about how to define 'affordability', and highlighted the limitations of the dominant ratio definitions (Hancock, 1993, p. 133; see also Bramley, 1994; Chaplin et al., 1994; Whitehead, 1991). Whitehead drew attention to the inherent inequity in ratio standards of housing affordability, which by definition accept inequity in housing standards, by acknowledging that the quality of housing available to households will be closely associated with the existing income distribution (Whitehead, 1991, p. 875): a given proportion of a high household income will give access to a higher quality of housing than the same proportion of a low household income. Others asserted that the weakness of ratio definitions lies in their inability to reveal anything about the critical relationship between housing and other costs: ratio definitions '[tell] us nothing about the impact of housing costs on a household's ability to fund other expenditures' (Kearns, 1992, p. 541).

Such critiques led to growing support for a residual income approach to defining housing affordability. In the early 1990s, a number of reports were published highlighting that it is the amount of money that households have left after paying for their housing that truly determines whether or not that housing is affordable to them (Brownill et al., 1990 and Sharp et al., 1990 cited in Stone, 2006b; see also Chaplin et al., 1994; Hancock, 1993; Maclennan and Williams, 1990). Housing analysts proposed measures of affordability that focus on the 'opportunity cost' of housing. That is, measures of housing affordability that determine 'what has to be foregone in order to obtain housing and whether that which is foregone is reasonable or excessive in some sense' (Hancock, 1993, p. 129). Put more simply, such measures ascertain whether a household is able to pay for their housing and 
able to afford 'a socially acceptable bundle of other goods' (Whitehead, 1991, p. 875) or 'the other necessities of life' (Chaplin et al., 1994, p. 6).

Figure 2. Residual Income measures of housing affordability

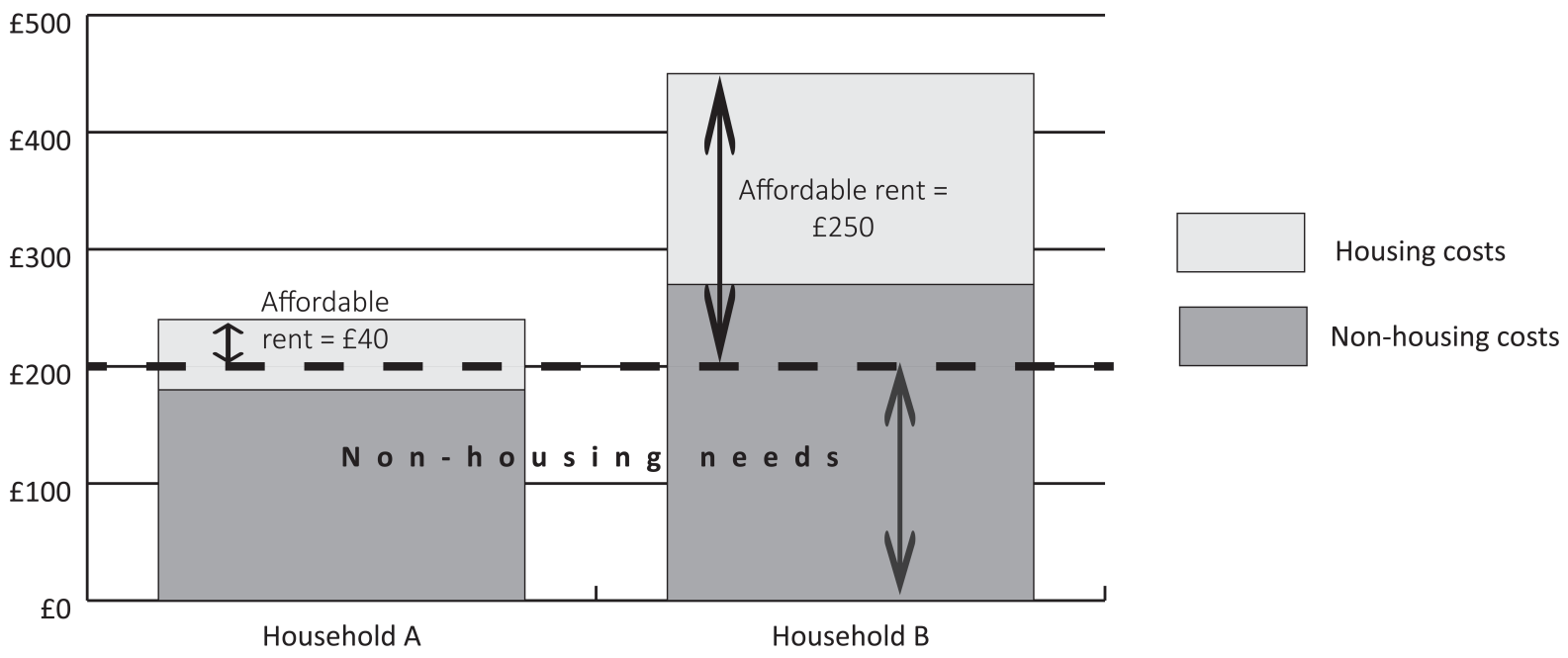

Notes: The residual income approach recognises that Household A can afford a smaller proportion of its income on rent after paying for their non-housing costs. If both households' non-housing needs amount to $£ 200$ per week, Household A can afford to pay $£ 40$ per week, or $17 \%$ of its income on rent, whereas Household B can afford $f 250$ - more than half its weekly income. It is therefore Household $A$ that has an affordability problem by this definition, despite paying a much lower proportion of its income on housing.

Although there has been some enthusiasm for the residual income approach, this has been accompanied by concerns about how to operationalise such measures of housing affordability. This has resulted in discussion about housing affordability recognising the merits of residual income, but analysis has continued to be dominated by ratio measures. This may in part be a consequence of the 'illusion' of international comparison of housing affordability levels, using ratio measures: it is possible to compare the proportion of the population who are spending more than 30 per cent of their income on housing in one 
country with the proportion spending above this level in another. However as Milligan (2003) outlines, there is little consistency across countries in what is included in 'housing costs'. There are similar variations in how income is defined within ratio measures, and whether, for example, this is gross household income or whether benefit income is included. Consequently, any international comparisons on this basis are problematic.

There are some exceptions to the dominance of ratio measures. For instance, Hancock (1993) used 100 and 140 per cent of Income Support levels in the UK as residual indicators to assess levels of housing affordability in Glasgow. More recently, the Cambridge Centre for Housing and Planning Research combined ratio and residual income criteria to define housing affordability, suggesting that a property was affordable to a household if it required them to spend no more than 35 per cent of their gross income on rent and left them with a residual income above 120 per cent of the applicable Income Support level (Whitehead et al., 2014; see also Tang, 2009). These two studies point to the key challenge in operationalising the residual income approach, namely how to define what constitutes a minimum residual income. The use of benefit levels to assess the adequacy of residual incomes is problematic because welfare provision is not based on any robust assessment of need, rather reflecting what is understood to be fiscally and ideologically acceptable by the political party in power (Kearns, 1992, pp. 542-3).

If benefit levels do not provide a suitable basis for calculating residual income, then is it possible to draw upon existing poverty lines? This is an approach that has been adopted in the United States, utilising poverty lines based on expenditure data. The federal poverty threshold in the US was first calculated in 1963 on the basis that a household needed three times the cost of a 'minimum' food diet in order to have an acceptable standard of living. This threshold is updated annually in line with CPI inflation, adjusted for household size and 
composition, and has been used as the residual income standard in studies of housing affordability in the US (see for example Kutty, 2005). However, such poverty lines are problematic in calculating whether families can afford what they need; households do not simply spend what they need to spend, and many spend more or less than they need to in order to have a decent standard of living. Use of expenditure data will therefore lead to a flawed minimum residual income standard. In the UK, it would not be possible to make use of existing poverty lines as the most commonly used line is a relative measure reflecting median incomes in that time and place. It therefore cannot be said to capture what households need to be able to afford to have a decent standard of living, and consequently does not provide a useful residual standard.

These problems with the use of benefit levels and poverty thresholds in calculating the adequacy of households' residual incomes have led to a recognition of the need for 'an independent, normative standard for residual income that is tied to neither the benefit systems nor the existing distribution of incomes' (Stone, 2006b, p. 457). Analysts such as Kearns (1992, p. 543) have argued that this level should represent a minimum standard of living rather than a subsistence level and so should include the costs of 'social expenditures', such as social participation, as well as 'essentials' such as food and clothing. In an attempt to identify an 'independent, normative standard', Stone (2006b) proposed a residual income approach for the UK making use of the Family Budget Unit (FBU) 'Low Cost but Acceptable' budgets as a normative standard for adequate residual income (see Parker (ed.) 1998). These budgets were intended to provide enough for households to be able to afford a decent, but not luxurious standard of living, based on expenditure data and expert opinion, with some consultation with members of low income households. However, the budgets applied to a limited range of family types, and were not updated to reflect changing social 
norms (Bradshaw et al., 2008, p. 2). Consequently, there is a limit to the usefulness of these budgets in describing and setting the level of a minimum residual income.

Budgets for a range of different households provided through MIS have replaced the budget standards compiled by the FBU. Updated annually since 2008, MIS is the income that different households need in order to reach a minimum socially acceptable standard of living in the UK today, based on what members of the public think (see Davis et al., 2016; Davis et al., 2017; Davis and Padley, 2017). Annual updates of MIS take two forms: new research with the public about what is needed for a minimum standard of living takes place every two years, with all households 'rebased' within a four year period; every other year, updates are based on changes in the prices of goods and services that comprise a minimum standard of living. The definition of what constitutes a minimum acceptable standard of living in contemporary UK society was constructed by groups of members of the public at the start of the research programme, in 2006: 'A minimum standard of living in the UK today includes, but is more than just, food, clothes and shelter. It is about having what you need in order to have the choices and opportunities necessary to participate in society' (Davis et al., 2016, p. 1). The MIS approach in the UK seeks first to describe what is needed in order to reach this minimum standard of living and then to detail the goods and services through which this living standard is met $^{1}$.

Detailed lists of goods and services are constructed through a process of consensus building with groups of members of the public from a range of socio-economic backgrounds, not just from low income households, across a range of locations. Different sets of groups discuss the needs of different households and specify the goods and services required by particular household compositions in order to meet their essential needs and participate in society (Davis et al., 2017). This process is repeated for eleven core households (Padley and 
Hirsch, 2017). The cost of these specified goods and services per week is used to calculate a weekly budget for each of these different household types. MIS has recently been updated to include distinct budgets for households living in Inner and Outer London, where differences in infrastructure, costs and ways of living mean that households have different needs to elsewhere in the country (Padley et al., 2015a, 2017a).

Critically in the context of defining and measuring housing affordability, the budgets produced through MIS offer a robust, regularly updated basis for defining what households need in order to 'achieve some minimum standard of nonshelter necessities' (Stone, 2006a, p. 163); that is, a means through which to define housing affordability in relation to the cost of other essentials, rooted in public consensus, bypassing the circularity of budget standards dependent on expenditure data. The budgets produced through MIS have been regularly updated through discussions with the public over the past decade, and there has been substantial stability and continuity in the contents of a minimum budget across household types (Davis et al., 2018). However, because MIS budgets are only fully rebased every four years, at these points a change in the contents of a minimum budget can introduce a sudden change in the income needed to reach a minimum living standard. For example, prior to 2012, the transport needs of households with children were met through public transport; in 2012, these households said that public transport was no longer sufficient to meet these minimum needs and consequently a second hand car was introduced into the minimum budgets for households with children (Davis et al., 2018, p. 22). Consequently, the analysis presented here makes use of MIS income requirements, covering the majority of the population (Padley et al., 2016), 'smoothed' over four years; this helps ensure that changes in MIS budgets are introduced gradually rather than at a single point in time. The 
next section outlines how MIS could be used as the basis for a comprehensive residual income approach to assessing levels of housing affordability in the UK.

\section{A UK housing affordability indicator based on the Minimum Income Standard}

Since 2013, Padley et al. (2013, 2014, 2015b, 2016, 2017b) have produced an annual analysis, using MIS budgets in combination with the Family Resources Survey (FRS) (DWP 2017b), providing an estimate of the prevalence of what Stone (1993) referred to as 'shelter poverty'; that is, the number and proportion of households unable to afford their minimum non-housing needs - as described through MIS - after housing costs (see Padley et al., 2017b). However, while this analysis points to the value of MIS in developing a measure of housing affordability, such a measure must also take into account housing costs themselves. That is, knowing which households are below MIS and how far short of meeting their essential needs they are is of value, but if MIS is to provide a basis for assessing housing affordability we also need to know which households are below MIS because of the cost of housing, and not because they have low incomes. Central to an exploration of the relationship between housing costs and income adequacy are two critical questions. First, what is meant by housing costs and second, at what level can housing costs be considered 'high'. As Milligan (2003) notes in relation to the challenges of comparing ratio measures internationally, housing costs can include a wide range of different costs, both direct - such as rent - and those associated with housing such as maintenance. A focus on direct costs as the basis for an indicator of housing affordability runs the risk of underestimating the costs that come with, for example, renting poor quality housing in the private sector or the costs of maintaining an ageing, owner-occupied property. The affordability measure, and 
subsequent analysis presented here, therefore use a measure of total housing $\operatorname{costs}^{2}$ that goes some way towards capturing the direct and indirect cost of housing. The second question concerning the level at which housing costs are considered 'high' is explored below.

Operationalising an affordability measure using MIS

MIS has not previously been used to assess the number and characteristics of households who have residual incomes below MIS as a direct result of 'high' housing costs (cf. Kutty, 2005). The analysis presented here set out to explore the feasibility of using MIS as a basis for a housing affordability measure, operationalising the residual income approach advocated by Stone, and starting from the principle that a household living within the rented sector in the UK can be defined as having a housing affordability problem if they have both 'high' housing costs and a residual income below MIS. In order to analyse the extent of the problem of housing affordability, it is first necessary to identify a threshold for what are considered to be 'high' housing costs for renters. The use of the term 'high' here is not unproblematic, particularly in light of the criticisms of ratio measures that are based on normative assumptions about 'high' or unaffordable housing costs. However, the term is used here in light of the evidence below.

In developing an affordability measure, a reasonable starting point is the proposition that households with modest incomes should be able to rent at a price that is broadly in line with the rents paid by other people with modest incomes. The crucial question is where the line can reasonably be drawn between 'high' housing costs, that have the potential to contribute to financial and/or material hardship, and housing costs that are not high. One possible starting point is to make use of evidence about the point at which low income 
households start to have payment problems because rent is too 'high' relative to income.

Bramley (2012), using data from the British Household Panel Survey, examined the relationship between different ratios of housing costs to income and self-reported payment problems regarding housing. He reported that where housing costs take up a quarter or more of household income, the risk of having problems with payments triples compared to the incidence for all households, but crucially there is little difference in risk when households are spending more than half of their income on housing compared to a quarter (ibid, p. 137). On this basis, for the purpose of this analysis a 'high' housing costs threshold can be reasonably based on the average proportion of net income taken up by housing costs, where this is above a quarter of net income, the point at which low residual income households have difficulty making ends meet, with an above-average rent ratio contributing to these difficulties.

Table 1 shows that based on this principle, households can be placed in one of four groups with regard to 'high' housing costs and household income.

Table 1. Identifying households with a housing affordability 'problem'

\begin{tabular}{lcc}
\hline No affordability 'problem' & $\begin{array}{c}\text { Household income above the } \\
\text { Minimum Income Standard }\end{array}$ & $\begin{array}{c}\text { Household income below the } \\
\text { Minimum Income Standard }\end{array}$ \\
\hline 'High' housing costs & $\begin{array}{c}\text { Affordability 'problem' is } \\
\text { housing related }\end{array}$ \\
Not 'high' housing costs & No affordability 'problem' & $\begin{array}{c}\text { Affordability 'problem' is } \\
\text { income related }\end{array}$ \\
\hline
\end{tabular}

For two groups, those with an income above MIS, there is no affordability problem. This categorisation points again to an issue with a ratio approach. The group with 'high' housing costs and an income above MIS may well be using a higher than average proportion of their 
income to meet their housing needs, but this is not resulting in insufficient income to meet non-housing needs. The other two groups, those with incomes below that needed to reach the socially acceptable minimum, have insufficient residual income for one of two reasons: either their household income is insufficient to reach MIS in spite of housing costs that are not 'high', or 'high' housing costs are a contributory factor to the household lacking what is required to meet non-housing needs.

Taking all of this into account, 'high' housing costs for households with someone in work are defined here as occurring when a household spends more on housing, after deducting housing benefit, as a proportion of their net income (after housing benefit) than the average proportion of net income taken up by housing costs for working households with below median income. Using Family Resources Survey (FRS) data from 2008/09 to $2015 / 16$, the average (mean) proportion of net income taken up by housing costs for every household in rented housing with at least one person in work, with below median equivalised income (BHC), in and outside London was calculated. The variation in these 'high' housing cost thresholds over time and location is explored below.

For households where nobody is in work - which are far more likely to have incomes below that needed for a minimum standard of living (Padley et al., 2017b) - the ratio of housing costs to income is not of critical importance (Joyce et al., 2017). More important is whether housing-related benefits cover all housing costs, or if households are having to use non-housing benefits to cover these, eating into what is available for non-housing needs. Households in which this is the case can be assumed to have their living standards lowered because of the burden of housing costs. Accordingly, high housing costs for working-age households where no one is in work are defined here as occurring when rental costs are greater than any housing-related benefits by at least $£ 5$ per week. The $f 5$ margin is set so as 
to avoid including those households who do have some very small charges classified as rent but which are ineligible for support.

\section{The variability of a 'high' housing costs threshold over time and location}

Analysis of the FRS makes it possible to chart the average proportion of net income (after housing benefit) taken up by housing costs (after housing benefit) for working households in the rented sector with below median income over time. Figure 3 shows that the average proportion of net income taken up by housing costs in the rented sector for these households has been relatively stable in the UK as a whole between 2008/09 and 2015/16. At the start of this period the average spent on housing by theses households was 43.2 per cent and by $2015 / 16$ this proportion had fallen slightly to 41.6 per cent. In London, the average proportion spent on housing costs at the start and the end of the period had also fallen slightly from 59 to 58.3 per cent in 2015/16. The changes in the proportion of income taken up by housing costs between 2008/09 and 2015/16 in and outside of London are broadly speaking what would be anticipated, given the changes in both rents and incomes over this period (Joyce et al., 2017, p18). However, it is clear from Figure 3 firstly that the proportion of income taken up by housing costs in London is significantly greater than in the UK outside of London and second, that there has been greater fluctuation in this average in London compared to the UK as a whole. 
Figure 3. Average proportion of net income (after housing benefit) taken up by housing costs (after housing benefit) for working households in the rented sector with below median income, $2008 / 09$ to $2015 / 16$

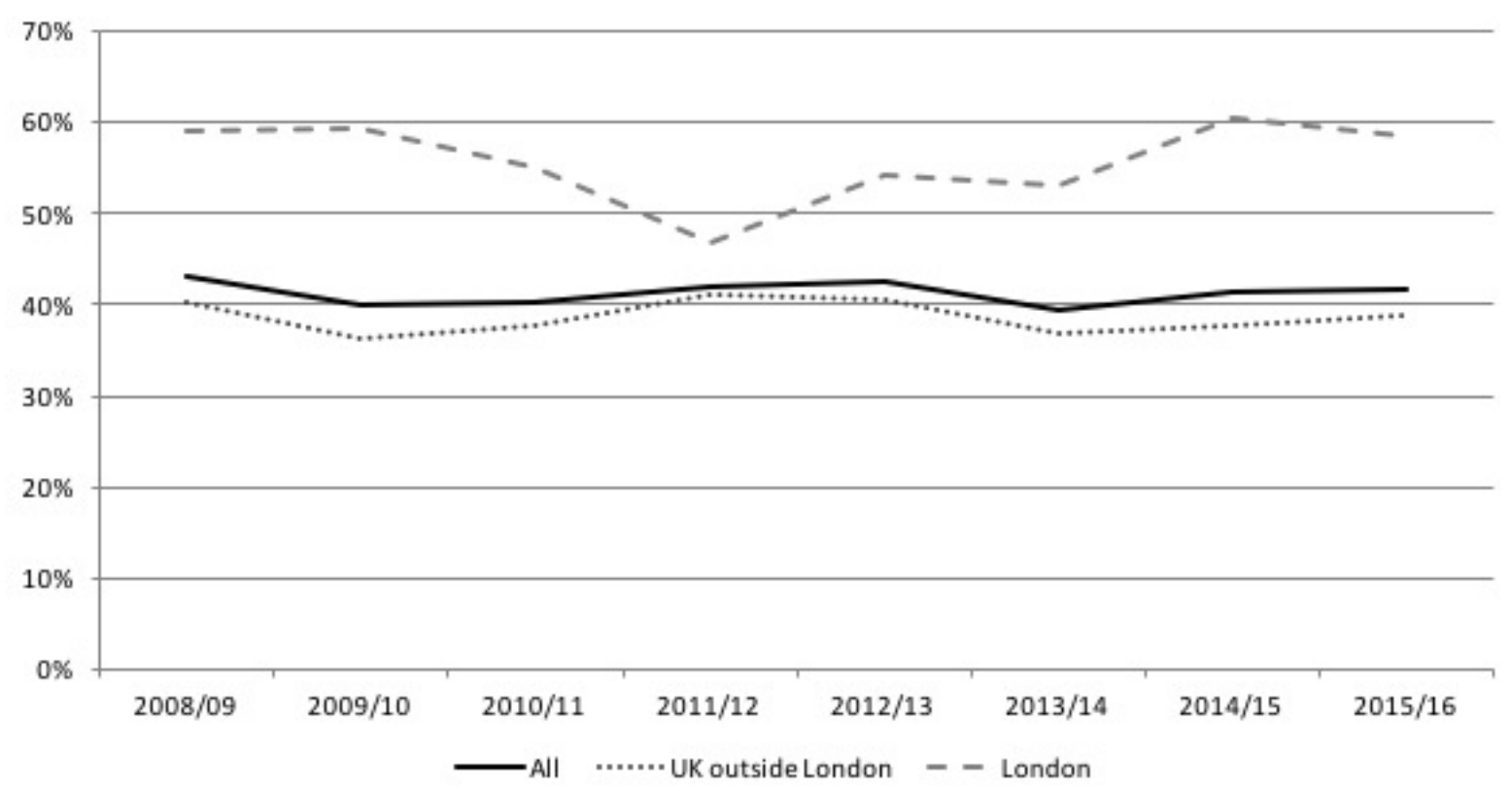

Using these thresholds in developing a housing affordability measure means that in 2008/09, for example, households renting in London are considered to have a housing affordability problem if they are spending more than 59 per cent of their net income on housing and if the income they have 'left over' is not enough to provide all that is needed for a minimum socially acceptable standard of living. The thresholds of 'high' housing costs that result from this analysis are higher than ratio measures of affordability resulting from alternative analyses. The English Housing Survey (DCLG, 2017) reports that private renters in London in 2015/16 were spending an average of 45 per cent of household income (including housing benefit) on rent, while outside London the average was 32 per cent. Analysis by the Institute for Fiscal Studies (Joyce et al., 2017) shows that in 2013-15 the median proportion of net household income spent on rent by private renters in was 40 per cent in London and 
28 per cent in the rest of Great Britain. However, in each of these analyses the focus is both on direct housing costs rather than on housing costs as a whole and on the PRS rather than all of the rented sector. Analysis undertaken by Corlett and Judge (2017) does look at housing costs relative to income, rather than at just the direct cost of rent or mortgages, and they find that private renters in 2015 are spending 35 per cent of income on housing, although this figure is for all private renters, across the income distribution rather than those below median income.

Figure 4. Average proportion of net income (after housing benefit) taken up by housing costs (after housing benefit) for working households in the rented sector with below median income, by region 2008/09 and 2015/16

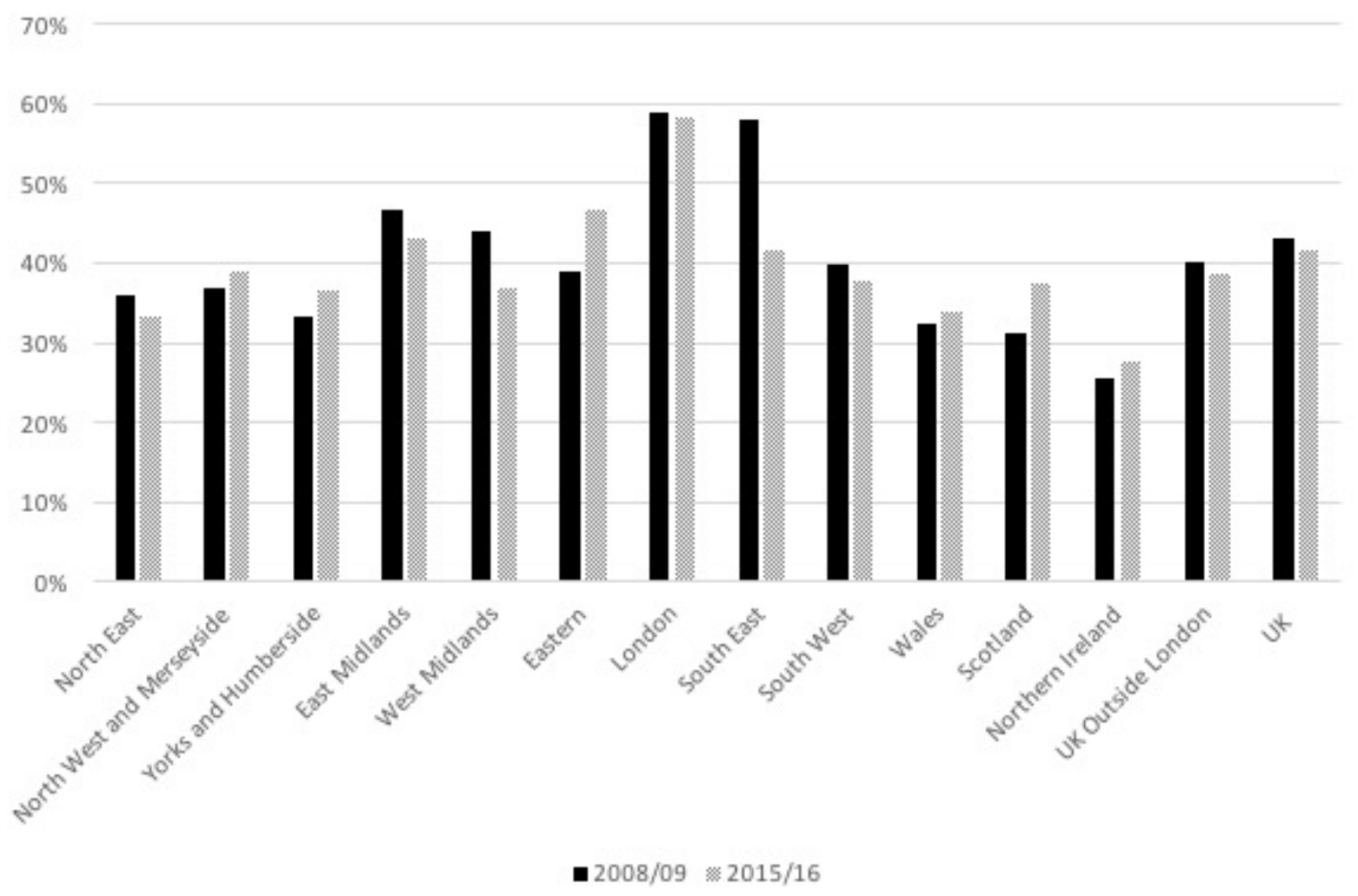


In addition to variation over time in the proportion of net income spent on housing costs, it is useful to explore how this 'high housing costs threshold' differs across UK regions. Figure 4 shows the variation in the average proportion spent on housing costs across regions in 2008/09 and 2015/16. Echoing other analyses looking at housing costs to income ratios (e.g. Banks and Whitehead, 2010; DCLG, 2017; Joyce et al., 2017) a far greater proportion of income is spent on housing in London compared to, for example, the North East and Northern Ireland. These regional differences in the threshold for 'high' housing costs, are a product of variation in both the cost of renting and incomes across regions between $2008 / 09$ and $2015 / 16$. These differences mean that in 2015/16 the 'high' housing costs threshold is below that for the UK outside London in seven regions. This is significant for any assessment of the scale of the problem of housing affordability as the proportion of households with 'high' housing costs, and with incomes below MIS as a consequence, will be directly affected by the level at which the threshold of 'high' housing costs is set. The analysis below looks at the impact of using these different thresholds.

\section{The extent of the housing affordability problem in the UK}

The purpose of this analysis was to explore how the threshold of 'high' housing costs varies over time and location, and then to look at what a housing affordability indicator based on MIS might reveal about the extent of the problem of affordability in the UK. While providing an insight into the scale of the problem within the UK, the principal purpose here is to illustrate the value of a residual income measure built on a robust living standards measure. In looking at housing affordability, this paper first makes use of the thresholds set out in Figure 3 as the basis for identifying 'high' housing costs and consequently for assessing the scale of the housing affordability problem in the UK between $2008 / 09$ and $2015 / 16$. It 
examines variation across tenure within the rented sector in this period and then makes use of regional 'high' housing costs thresholds to explore the impact of these on assessments about housing affordability.

Figure 5. Proportion of working-age households in the rented sector with a housing affordability problem, 2008/09 to 2015/16

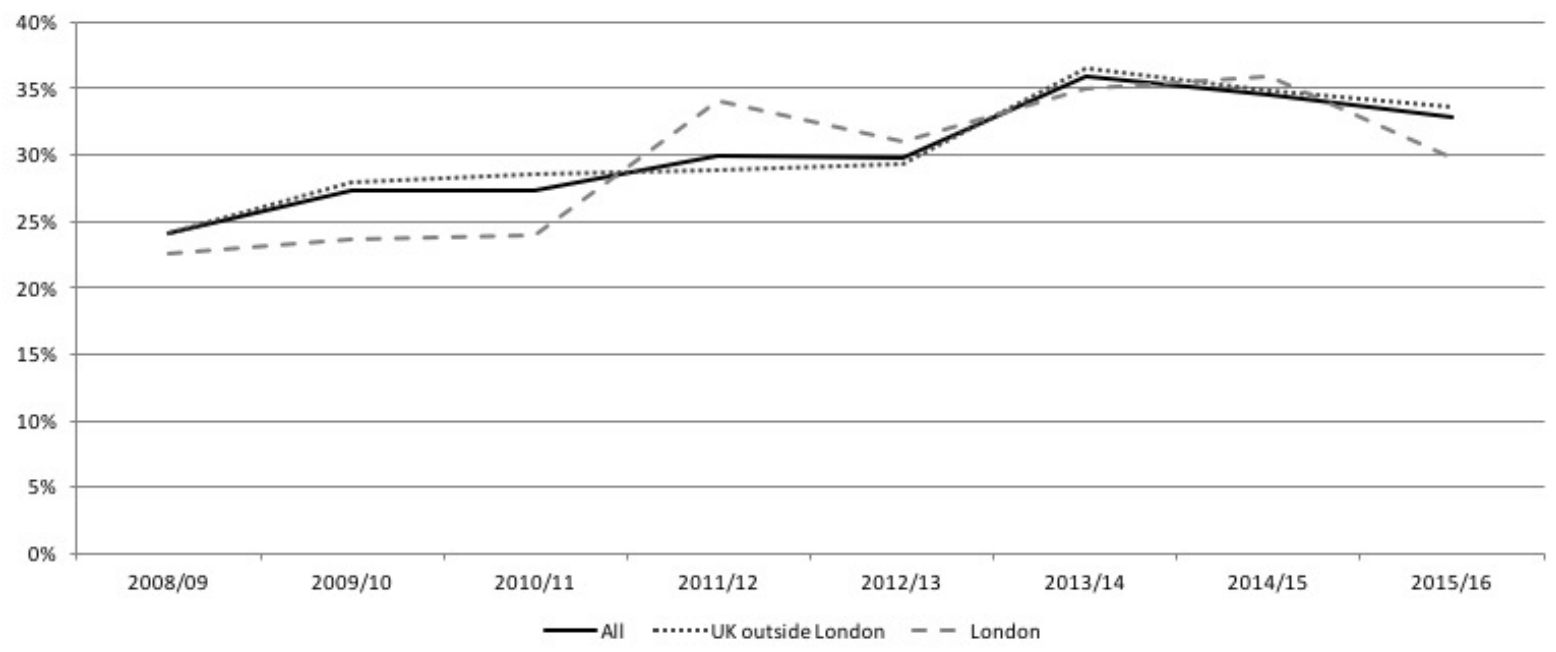

Figure 5 shows the proportion of households in the UK, in London and in the UK outside London with both 'high' housing costs and incomes below MIS between 2008/09 and 2015/16. The MIS benchmarks used in this analysis relate to urban areas in the UK and do not vary across or within regions; the exception here is London, where an ongoing programme of research has established how minimum needs and costs are different within the capital (Padley et al., 2017a). In 2008/09, just under one quarter (24.2 per cent) of all UK households in the rented sector had incomes below that needed for a minimum socially acceptable standard of living and had 'high' housing costs; that is, after paying for housing around a quarter of households did not have enough disposable income to meet their non- 
shelter needs. The proportion of UK households who could be described as having an affordability problem increased each year between 2008/09 and 2013/14, and since this point has fallen back. However, a third of UK households in the rented sector in 2015/16 had an affordability problem, an increase from 2008/09.

This growing affordability problem echoes, and is in part explained by, political and economic changes following from the financial crisis of 2008 (Clarke et al., 2016). Between 2008/09 and 2013/14 real average earnings fell substantially and it was not until towards the end of 2014 that earnings started to increase (Corlett et al., 2017). Median equivalised household incomes also fell year on year between 2008/09 and 2012/13 (Corlett and Clarke, 2017). At the same time, private rents, particularly in the lower quartile, continued to increase, while rents in the social housing sector saw substantial increases, until reductions introduced by then Chancellor of the Exchequer in the UK George Osborne came into force in April 2016. Compounding a lack of growth in earnings and increases in the cost of housing over this period were changes in eligibility for, and the level of, state support for a range of households introduced through the UK Welfare reform act in 2012. The net effect of this bundle of changes is that housing costs for those in the rented sector accounted for a growing proportion of household income and consequently the income 'left-over' to cover non-shelter needs reduced. Adding to this strain on incomes, the cost of a minimum basket of goods and services - or non-shelter needs - has also increased, ahead of inflation, since 2008/09 (Davis et al., 2018, pp. 38-42). The continued increase in the number of households in the private rented sector, allied to the growing proportion with insufficient income to cover 'high' housing costs and minimum non-shelter needs, means that the number of households that can be considered to have a housing affordability problem, in the terms set out here, more than doubled from 1.2 million in 2008/09 to 2.6 million in 2015/16. 
Focusing on tenure reveals clear differences in the proportion of households with a housing affordability problem, both in London and in the UK outside London. Figure 6 shows the proportion of social and private renters with 'high' housing costs and incomes below MIS between 2008/09 and 2015/16. A distinction is clear between the scale of the housing affordability problem in the social rented sector and in the PRS. In both London and the UK outside London, a greater proportion of households in the social rented sector have an affordability problem compared to those in the PRS: in 2015/16, 46 per cent of social renting households in London have an affordability problem, compared to 28 per cent of households in the PRS, while in the UK outside London, 40 per cent of households in social rented properties have an affordability problem compared with 21 per cent in the PRS. This difference is perhaps unsurprising given that social renting households are more likely to have incomes in the bottom third of the income distribution (Belfield et al., 2015), which are less likely to cover both housing and non-shelter needs. Changes in housing benefit policy also mean that households in social housing are more likely in $2015 / 16$ to have to meet some of their housing costs than they were in 2008/09. Joyce et al. $(2017$, p27) show that between 2010 and 2015 there has been a large increase in the proportion of low income households in social housing with a shortfall between housing benefit and rent; a growing proportion of social renter households are having to cover some of their housing costs from available income, reducing the income 'left' to cover the cost of a minimum socially acceptable standard of living. More generally, real social rents in both London and the UK outside London increased in the period between 2008/09 and 2013/14, while real incomes for social renters remained flat, meaning that housing costs increased relative to incomes. 
Figure 6. Proportion of working-age households in the rented sector with a housing affordability problem, $2008 / 09$ to $2015 / 16$, by tenure

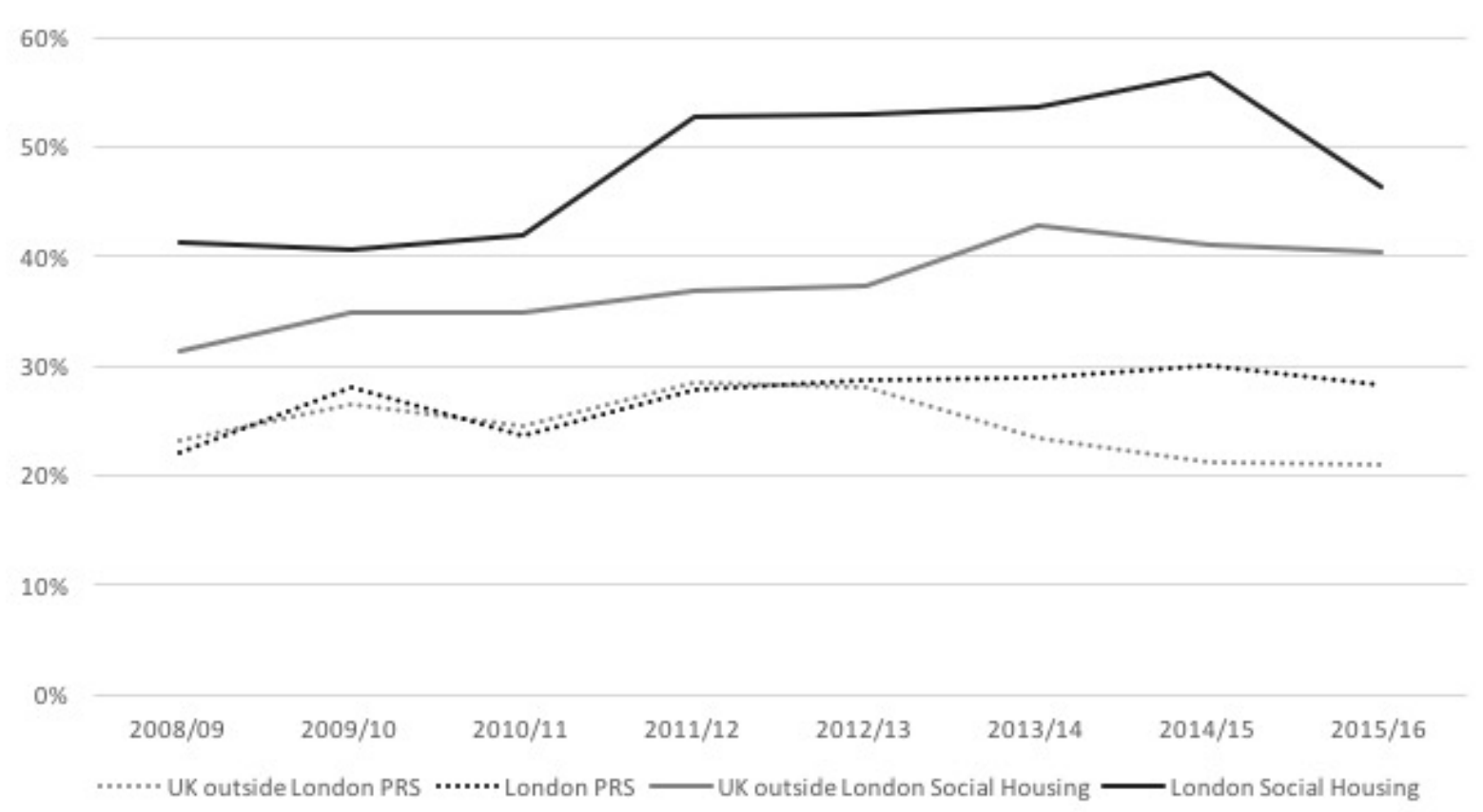

Figure 6 also shows a divergence since 2012/13 in the proportion of households with a housing affordability problem in the PRS in London and the UK outside London. Between 2008/09 and 2012/13, the proportion of private renting households with an affordability problem in London and outside London was broadly similar. Since this point, the gap between the proportion of private renting households in London and outside London with an affordability problem has grown. This growing gap is likely a consequence of trends in incomes and private rents in London and the rest of the UK, and a product of changes in the levels of support for housing costs for those in the PRS. Private rents in London have increased at a greater rate than outside London, particularly since $2012 / 13$, and private renters in London have seen an increase in the proportion of income spent on housing while this has remained relatively flat outside London (Joyce et al., 2017). This means that a growing proportion of private renters have 'high' housing costs, without incomes growing to 
cover these; the result is that the income 'left' to cover non-housing costs - or to meet minimum non-shelter needs - has fallen as housing costs have increased. Restrictions on the levels of support available through housing benefit are also likely to have had an impact on the proportion of private renting households with an affordability problem. Analysis of the shortfall between housing benefit and rent (ibid) shows that in London in 2015, 92 per cent of low income private renting households had a shortfall between rent and housing benefit and that over 40 per cent of these households had a shortfall of at least half of their income.

Using the measure of housing affordability proposed here, it is clear that a growing proportion of UK households in rented accommodation, in and outside London, do not have the income needed for a minimum socially acceptable standard of living because 'high' housing costs are reducing the income available to cover these non-shelter needs. Using a UK-level 'high' housing costs threshold, a third of all households in rented accommodation can be considered to have a housing affordability problem (Figure 5). There are differences in the scale of the problem between London and the UK outside London, but as indicated in Figure 4, there are also differences across regions both with regard to the average proportion being spent on housing and the implications of this for understanding of the scale of the housing affordability problem.

Figure 7 shows the proportion of households in the rented sector with a housing affordability problem, using the regional 'high' housing costs thresholds shown in Figure 4. In general, this analysis shows that with the exception of Scotland, the proportion of households with a housing affordability problem has increased in all regions between $2008 / 09$ and $2015 / 16$. The region with the greatest proportion of households with a housing affordability problem in 2008/09 was the North East, where a substantially higher proportion of households had an affordability problem compared to the UK as a whole. In 
$2015 / 16$, Wales is the region with the largest proportion of households with an affordability problem and is also the region in which there has been the greatest percentage point increase over this period; nearly half of all households in the rented sector in Wales had a housing affordability problem in $2015 / 16$. Scotland and Northern Ireland are the regions with the smallest proportion of renting households with an affordability problem, and in both regions the proportion with a problem is substantially below the proportion for the UK as a whole, based on a national-level 'high' housing costs threshold.

Figure 7. Proportion of working-age households in the rented sector with a housing affordability problem, 2008/09 and 2015/16, by region

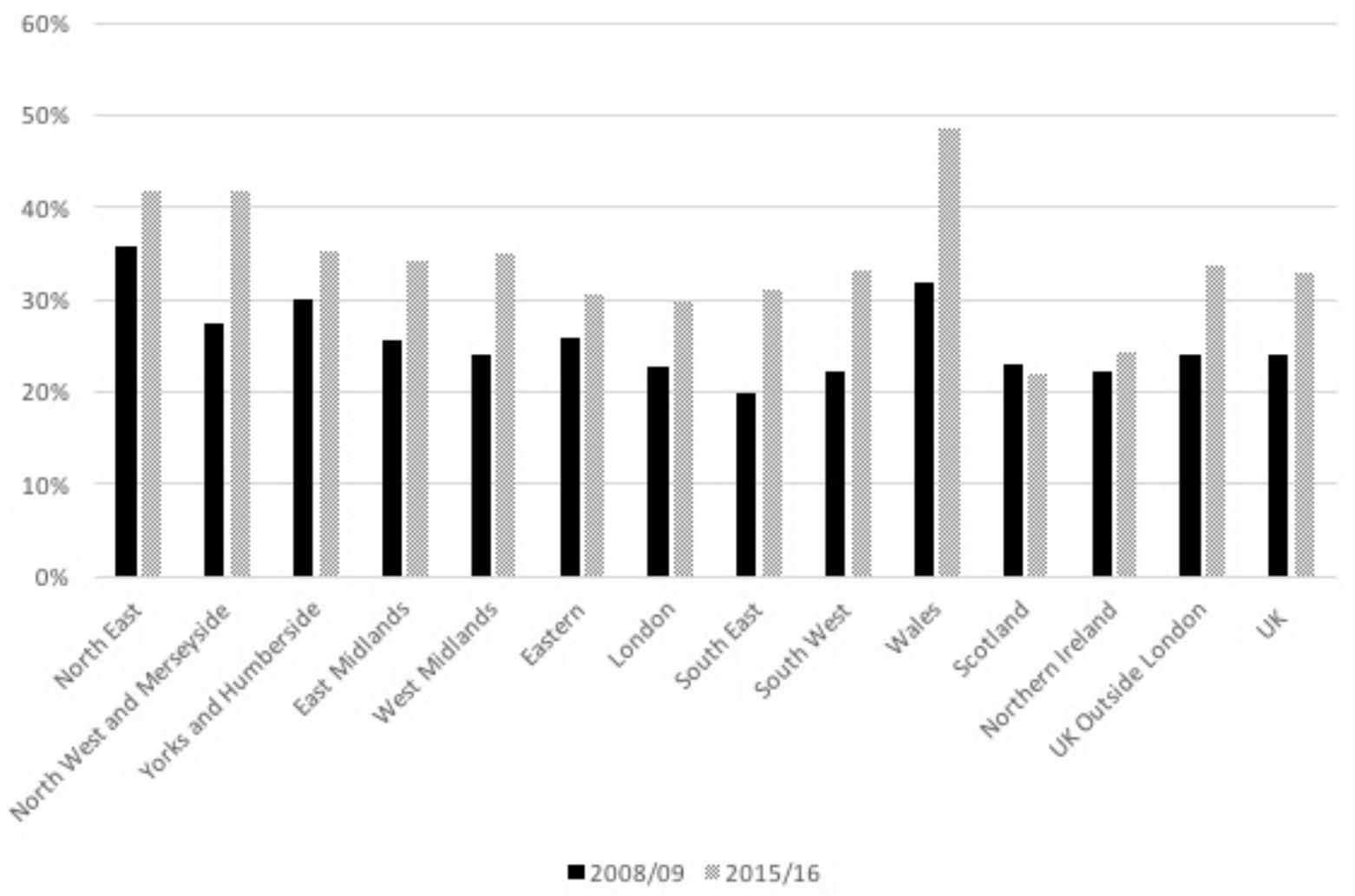

Making use of these regional rather than national-level 'high' housing costs thresholds as the basis for assessing the scale of affordability provides a more nuanced account of the 
problem. While it is widely acknowledged that housing affordability in London is of particular concern in the UK context (Clarke et al., 2016), Figure 7 shows that relative to other regions, the 'problem' facing London is not necessarily as significant in scale as the challenges facing the North of the UK or the Midlands. This is because the housing affordability problem is not just one of housing supply, or the availability of low cost housing, but is closely linked to differences in household incomes across the UK. Using a housing affordability indicator based on MIS, what is needed for a minimum socially acceptable standard of living in the UK outside London does not vary significantly, but the ability of households to reach the income needed to meet these needs and cover the cost of housing does. What is clear in using a more granular 'high' housing costs threshold is that in some regions the possibility of meeting a minimum living standard is being challenged by the high cost of housing relative to income (cf. Clarke et al., 2016).

\section{Summary and conclusions}

The central purpose of this paper was to explore the possibility of developing a residual income measure of housing affordability based on MIS and to look at what such a measure, when applied, might tell us about the scale of the current housing affordability problem within the UK. The analysis presented here shows that while there has been little change over time in 'high' housing costs threshold at a UK level, the proportion of households with incomes below that needed for a minimum socially acceptable standard of living because of 'high' housing costs has increased in the UK as a whole. Given the broader circumstances of recent years, with a growing dependence on private renting, rising rents and stagnating real wages it is not surprising that the housing affordability indicator proposed here has shown this change over time. Despite a recent small upturn in earnings, housing costs are in 
general placing an increasing burden on household finances, and on government finances, through a growing Housing Benefit bill, with around one third of recipients now in the private sector, nearly half of whom are in work (National Housing Federation, 2016). While reductions in and restrictions on the level of support provided to households through housing benefit may serve to reduce the burden on the government's welfare spending, these reforms to state support serve only to exacerbate the housing affordability problems faced by many households.

These problems are particularly acute in the social rented sector, and particularly in London where just over a fifth of working-age households are still living in social housing (Clarke et al., 2016) and where 46 per cent of these households have a housing affordability problem in the terms set out here. While information about the scale of the affordability problem is of value, it is important to consider if a more sophisticated housing affordability indicator could point towards possible policy solutions. Dolphin Living (2016) have recently adopted a residual income approach to personalised rent setting on a small scale, based on MIS data, and echoing the approach to measuring housing affordability developed here. Their personalised rent policy starts from the premise that the relationship between rent and residual income is a critical one. Under this policy tenants household income is directly compared to the particular household needs set out in MIS, with these needs subtracted from net household income. The residual that is 'left' after covering non-shelter needs is then used to set rents either on the basis that households are able to pay more than current rent levels or that current rent levels take up all of what is left. Clearly there are challenges in establishing such an approach to rent setting on a larger scale across, for example, local authorities, but the principle that non-shelter minimum needs should be taken into account when setting rents is one worthy of further consideration. 
A more general policy response to the challenge of housing affordability in the rented sector has been the emergence of the concept of a 'living rent', an idea suggested by a growing number of commentators, charities and housing pressure groups as a possible 'solution'. London Mayor Sadiq Khan has announced a 'London Living Rent Scheme' offering new-build affordable homes to particular low and middle-income households, with rents set at a third of average local incomes. While this will benefit selected households, unlike the personalised rent scheme it is predicated on a concept of affordability that takes no account of what households need to spend on non-housing items. Problematically the term affordable is being used in an only very loosely defined way as it is so often in other suggested proposals for living rents, rent caps or more affordable housing.

As well as the possibility of personalised rents making use of a residual income approach, the analysis presented here also points to the importance of developing local measures of housing affordability. While, in urban areas in the UK outside of London, what is needed for a minimum socially acceptable standard of living does not vary by region, there is clearly merit in developing measures that take into account local circumstances with regard to the relationship between incomes and housing costs. Such local measures would also be of more value in terms of assessing the impact and the effectiveness of both existing and proposed policy responses to the housing affordability challenge at a local level. For example, the impact of capping rents at a particular level in a given location could be assessed, identifying the level at which private or social rents could be set in order for those most at risk of having a residual income below MIS because of 'high' housing costs to be lifted out of their affordability problem. Given the evidence presented here, this level would be very different in Wales, for example, compared to Scotland. The argument for housing affordability measures that are more sensitive to local circumstances is one that has been 
made by others (e.g. Baxter and Murphy, 2017), but this would seem to be a particularly valuable use of the measure set out and developed in this paper.

Clearly, however, the development of better affordability measures, reflecting local circumstances is not a 'magic bullet' to solve the housing affordability problem. Neither is it necessarily the case that the 'problem' of housing affordability can be solved mechanistically by restricting rents to an appropriate level. Housing affordability is not simply a housing question requiring housing solutions; it also necessitates addressing big questions about income and the role of state support. There are also clearly critical questions about the quality of housing that need to be addressed. That said, it is only with fundamental change in housing supply alongside structural changes in tenure patterns can a sufficient number of affordable homes be made available to people on low incomes. The indicator proposed here could add significantly to the debate on the future of housing, but there is much work to be done in order to ensure that this 'crisis' of affordability does not become a long-lasting and persistent reality.

\footnotetext{
${ }^{1}$ Detailed lists of the goods and services that the public agree are needed for a minimum socially acceptable standard of living, for a range of different household compositions, are available at: http://www.crsp.ac.uk/mis/results. Items within these detailed lists are arranged by commodity groups: food (in and outside the home), alcohol (in and outside the home), clothing and footwear, rent, water rates, council tax, household insurances, fuel, home maintenance, household goods, household services, childcare, personal goods and services (including health costs), motoring, bus and coach travel, other travel costs, leisure goods and leisure services.

2 Total housing costs includes the total amount spent on water and sewerage rates, rent, mortgage interest, household rent, structural insurance and service charges. These include the following: - rent (gross of housing benefit); · water rates, community water charges and council water charges; · mortgage interest payments; · structural insurance premiums (for owner occupiers); · ground rent and service charges
} 


\section{References}

Alakeson, V. and Cory, G. (2013) Home Truths: How affordable is housing for Britain's ordinary working families? London: Resolution Foundation.

Austin, P., Gurran, N. and Whitehead, C. (2014) Planning and affordable housing in Australia, New Zealand and England: common culture; different mechanisms, Journal of Housing and the Built Environment, 29, pp. 455-472.

Banks, D. and Whitehead, C. (2010) Cross Tenure Rents and Affordability, 2008/09 update Cambridge: Cambridge Centre for Housing and Planning Research.

Baxter, D. and Murphy, L. (2017) Priced out? Affordable housing in England London: Institute for Public Policy Research.

Belfield, C., Chandler, D. and Joyce, R. (2015) Housing: trends in prices, costs and tenure London: Institute for Fiscal Studies.

Bradshaw, J., Middleton, S., Davis, A., Oldfield, N., Smith, N., Cusworth, L. and Williams, J., (2008) A Minimum Income Standard for Britain: What people think York: Joseph Rowntree Foundation.

Bramley, G. (1994) An Affordability Crisis in Britain: Dimensions, Causes and Policy Impact, Housing Studies, 9(1), pp. 103-24. 
Bramley, G. (2012) Affordability, poverty and housing need: triangulating measures and standards, Journal of Housing and the Built Environment, 27(2), pp. 133-151.

Brownill, S., Sharp, C. Jones, C. and Merrett, S. (1990) Housing London York: Joseph Rowntree Foundation.

Chaplin, R. and Freeman, A. (1999) Towards an accurate description of affordability, Urban Studies, 36(11), pp. 1949-1957.

Chaplin, R., Martin, S., Yang, J.H. and Whitehead, C. (1994) Affordability: Definitions, Measures, and Implications for Lenders Cambridge: Cambridge University, Department of Land Economy.

Clarke, S., Corlett, A. and Judge, L. (2016) The housing headwind: The impact of rising housing costs on UK living standards London: Resolution Foundation.

CoreLogic (2016) Housing Affordability Report: December 2016. Available at: http://www.corelogic.com.au/reports/CL Housing-Affordbality-Dec 2016.pdf (Accessed 5 September 2017)

Corlett, A. and Judge, L. (2017) Home Affront London: Resolution Foundation.

Corlett, A., Clarke, S. and Tomlinson, D. (2017) The Living Standards Audit 2017 London: Resolution Foundation. 
Davis, A., Hill, K., Hirsch, D. and Padley, M. (2016) A Minimum Income Standard for the UK in 2016 York: Joseph Rowntree Foundation.

Davis, A., Hirsch, D., Padley, M. and Shepherd, C. (2018) A Minimum Income Standard for the UK, 2008-2018: continuity and change York: Joseph Rowntree Foundation.

Department for Communities and Local Government (2017) English Housing Survey, Households: Annual report on England's households, 2015-16 London: DCLG.

Department for Work and Pensions (2017a) Households Below Average Income: An analysis of the income distribution 1994/95 - 2015/16 London: DWP.

Department for Work and Pensions (2017) Family Resources Survey 2015/16 London: DWP.

Dolphin Living (2016) New Era Rent Setting Policy London: Dolphin Living. Available at: http://dolphinliving.com/wp-content/uploads/New-Era-Rent-Setting-Policy-2015-16v1.3.pdf (Accessed 6 September 2017).

Feins, J. and Lane, T. (1981) How Much for Housing? (Cambridge, MA: Abt Associates, Inc.).

Gabriel, M., Jacobs, K., Arthurson, K., Burke, T. and Yates, J. (2005) Conceptualising and measuring the housing affordability problem, National Research Venture 3: Housing 
Affordability for Lower Income Australians, Research Paper 1, Melbourne: Australian Housing and Urban Research Centre.

Gilbert, A. (2015) Rental Housing: The International Experience, Habitat International, 54, pp. 173-181.

Grigsby, W.G. and Rosenburg, L.S. (1975) Urban Housing Policy (New York: APS Publications).

Gurran, N. and Phibbs, P. (2015) Are Governments Really Interested in Fixing the Housing Problem? Policy Capture and Busy Work in Australia, Housing Studies, 30(5), pp. 711-729.

Gurran, N. and Whitehead, C. (2011) Planning and Affordable Housing in Australia and the UK: A Comparative Perspective, Housing Studies, 26(7-8), pp. 1193-1214,

Hancock, K.E. (1993) Can't Pay? Won't Pay? The Economic Principles of Affordability, Urban Studies, 30(1), pp. 127-45.

Hirsch, D. (2015) A Minimum Income Standard for the UK in 2015 York: Joseph Rowntree Foundation.

Hui, E. (2001) Measuring affordability in public housing from economic principles: case study of Hong Kong, Journal of Urban Planning and Development, 127(1), pp.34-49. 
Joyce, R., Mitchell, M. and Keiller, A. (2017) The cost of housing for low-income renters London: Institute for Fiscal Studies.

Karmel, R. (ed.) (1998) Housing Assistance: Reports on Measurement and Data Issues, Working Paper no. 17, Welfare Division, Australian Institute of Health and Welfare, Canberra.

Katz, B., Turner, M., Brown, K., Cunningham, M. and Sawyer, N. (2003) Rethinking Local Affordable Housing Strategies: Lessons from 70 Years of Policy and Practice, Brookings Institute Center on Urban and Metropolitan Policy and Urban Institute, Washington. Available at http://www.brookings.edu/dybdocroot/es/urban/vouchers/report.pdf (Accessed 6 September 2017).

Kearns, A. (1992) Affordability for Housing Association Tenants, Journal of Social Policy, 21(4), pp. 523-547.

Klier, S. (2015) How the Next Mayor of London Can Start Fixing the Housing Crisis, Generation Rent blog. 06 August. Available at http://www.generationrent.org/how the next mayor of london can start fixing the ho using crisis (Accessed 2 September 2015).

Kutty, N.K. (2005) A New Measure of Housing Affordability: Estimates and Analytical Results, Housing Policy Debate, 16(1), pp. 113-42. 
Labour Press (2015) Ed Miliband launches election campaign with rents pledge [Press release]. Available at http://press.labour.org.uk/post/84352297129/ed-miliband-launcheselection-campaign-with-rents. (Accessed 21 July 2015).

The Land Registry (2017) Land Registry House Price Index August 2017. Available at http://landregistry.data.gov.uk/app/ukhpi/explore (Accessed 6 September 2017).

London Citizens (2016) London Citizens Housing Manifesto 2016 London: London Citizens.

London Fairness Commission (2016) London Fairness Commission Final Report London: Toynbee Hall.

Maclennan, D. and Williams, R. (1990) Introduction, in: D. Maclennan and R. Williams (Eds) Affordable Housing in Britain and the United States York: Joseph Rowntree Foundation.

Mann, S. (2015) Calls for rent cap in London grow after policy is introduced in Berlin, London Evening Standard, 02 June. Available at http://www.standard.co.uk/news/london/londonshould-follow-berlin-calls-for-rent-cap-in-capital-grow-after-policy-is-introduced-ingermany-10292602.html (Accessed 21 July 2015).

Milligan, V. (2003) How Different? Comparing Housing Policies and Housing Affordability Consequences for Low Income Households in Australia and the Netherlands, Netherlands Geographical Studies, no. 318, University of Utrecht, Utrecht. 
Murphy, L. (2014) 'Houston, we've got a problem': The Political Construction of a Housing Affordability Metric in New Zealand, Housing Studies, 29(7), pp. 893-909.

National Housing Federation (2016) The growing Housing Benefit spend in the private rented sector. Available at http://s3-eu-west-

1.amazonaws.com/pub.housing.org.uk/Housing Benefit and the private rented sector.p df (Accessed 12 September 2016).

National Union of Students (2016) Double Jeopardy: Assessing the dual impact of student debt and graduate outcomes on the first $f 9 k$ fee paying graduates. Available at http://www.nus.org.uk/PageFiles/12238/Double Jeopardy.pdf (Accessed 12 September 2016).

Newman, S. and Holupka, C. (2015) Housing Affordability and Child Well-Being, Housing Policy Debate, 25(1), pp. 116-151.

New Zealand Productivity Commission (2012) Housing Affordability. Available at: http://www.productivity.govt.nz/sites/default/files/Final Housing Affordability Report 0 0.pdf (Accessed 6 September 2017)

Office for National Statistics (2017) Annual Survey of Hours and Earnings: 2017 provisional and 2016 revised results. Available at 
https://www.ons.gov.uk/employmentandlabourmarket/peopleinwork/earningsandworking hours/bulletins/annualsurveyofhoursandearnings/2017provisionaland2016revisedresults (Accessed 26 October 2017).

Parker, H. (1998) Low Cost but Acceptable: A minimum income standard for the UK: Families with young children Bristol. Policy Press.

Padley, M., Valadez-Martinez, L. and Hirsch, D. (2017b) Households below a Minimum Income Standard: 2008/09 to 2015/16 York: Joseph Rowntree Foundation.

Padley, M., and Hirsch, D. (2017) A Minimum Income Standard for the UK in 2017 York: Joseph Rowntree Foundation.

Padley, M. and Hirsch, D. (2016) Households below a Minimum Income Standard: 2008/09 to 2013/14 York: Joseph Rowntree Foundation.

Padley, M., Valadez, L. and Hirsch, D. (2015b) Households below a minimum income standard: 2008/09 to 2012/13 York: Joseph Rowntree Foundation.

Padley, M. and Hirsch, D. (2014) Households below a Minimum Income Standard: 2008/9 to 2011/12 York: Joseph Rowntree Foundation.

Padley, M. and Hirsch, D. (2013) Households below a Minimum Income Standard: 2008/09 to 2010/11 York: Joseph Rowntree Foundation. 
Padley, M., Davis, A., Hirsch, D., Horsley, N. and Valadez, L. (2017a) A Minimum Income Standard for London 2016/17 London: Trust for London.

Padley, M., Marshall, L., Hirsch, D., Davis, A. and Valadez, L. (2015a) A Minimum Income Standard for London London: Trust for London.

Pedone, C. (1988) Current Housing Problems and Possible Federal Responses Washington DC: Congressional Budget Office.

PWC [PricewaterhouseCoopers] (2015) UK Economic Outlook London: PWC.

Reynolds, L. (2011) Private Rent Watch. Report 1: Analysis of local rent levels and affordability London: Shelter

Savills (2015) Spotlight: Prime Rental Markets. Available at http://pdf.euro.savills.co.uk/uk/residential---other/spotlight-prime-rental-markets.pdf (Accessed 23 September 2015).

Sharp, C., Jones, C., Brownill, S. and Merrett, S. (1990) What Londoners Pay for their Housing London: SHAC.

Shelter (2015) Making Renting Fit for Families: The impact of different forms of rent regulation London: Shelter. 
Statistics New Zealand (2013) Rental affordability 1998-2012: Regional Distributions. Available at: $\underline{\text { http://m.stats.govt.nz/ /media/Statistics/browse-categories/people-and- }}$ communities/housing/rental-affordability-1998-2012/rental-affordability-1998-2012.pdf (Accessed 5 September 2017).

Stone, M.E. (1975) The Housing Crisis, Mortgage Lending, and Class Struggle, Antipode, 7, pp. 22-37.

Stone, M.E. (1993) Shelter Poverty: New Ideas on Housing Affordability (Philadelphia: Temple University Press).

Stone, M.E. (2006a) What is Housing Affordability? The case for the residual income approach, Housing Policy Debate, 17(1), pp. 151-184.

Stone, M.E. (2006b) A Housing Affordability Standard for the UK, Housing Studies, 21(4), pp. 436-476.

Tang, C. (2009) Affordability of Housing Association Rents: Rent-to-Income Ratio vs. Residual Income Cambridge: Cambridge Centre for Housing and Planning Research.

US Bureau of Labor Statistics (2015) Consumer Expenditures in 2013, BLS Report 1053 Washington, D.C.: Bureau of Labor Statistics. 
VOA [Valuation Office Agency] (2011) Private Rental Market Statistics (England only), Statistical bulletin released 29 September. Available at

http://www.voa.gov.uk/corporate/statisticalReleases/110929 PrivateResidentialRentalMar ketStatistics.html (Accessed 22 July 2014).

VOA (2016) Private Rental Market Statistics (England only), Statistical bulletin released 17 November. Available at https://www.gov.uk/government/statistics/private-rental-marketsummary-statistics-october-2015-to-september-2016 (Accessed 5 September 2017).

Whitehead, C. (1991) From Need to Affordability: An Analysis of UK Housing Objectives, Urban Studies, 28(6), pp. 871-87.

Whitehead, C., Udagawa, C. and Fenton, A. (2014) Housing Costs, Affordability and Rent Setting: A report to Affinity Sutton from the Cambridge Centre for Housing and Planning Research Cambridge: CCHPR.

Wilcox, S. (1999) The Vexed Question of Affordability, Edinburgh, Scotland: Scottish Homes.

Wiles, C. (2014) 'Affordable housing does not mean what you think it means'. Guardian [online]. Available at https://www.theguardian.com/housingnetwork/2014/feb/03/affordable-housing-meaning-rent-social-housing (Accessed 11 September 2015). 
Wilson, W. and Morgan, B. (1998) Rent Levels, Affordability, and Housing Benefit, Research Paper 98/69 London: House of Commons Library.

Yip, N. (1995) Housing Affordability in England, D. Phil. Thesis, University of York, Department of Social Policy and Social Work. 